Hydrol. Earth Syst. Sci. Discuss., 8, 2477-2501, 2011

www.hydrol-earth-syst-sci-discuss.net/8/2477/2011/

doi:10.5194/hessd-8-2477-2011

(c) Author(s) 2011. CC Attribution 3.0 License.
Hydrology and

\title{
Impacts of agricultural intensification through upscaling of suitable rainwater harvesting technologies in the upper Ewaso Ngiro North basin, Kenya
}

\section{J. K. Mutiga, S. Zhongbo, and T. Woldai}

Faculty of Geo-Information, Science and Earth Observation, University of Twente, The Netherlands

Received: 3 January 2011 - Accepted: 29 January 2011 - Published: 7 March 2011

Correspondence to: J. K. Mutiga (kinotijk@gmail.com)

Published by Copernicus Publications on behalf of the European Geosciences Union.

\section{HESSD}

8, 2477-2501, 2011

Impacts of agricultural intensification in

Kenya

J. K. Mutiga et al.

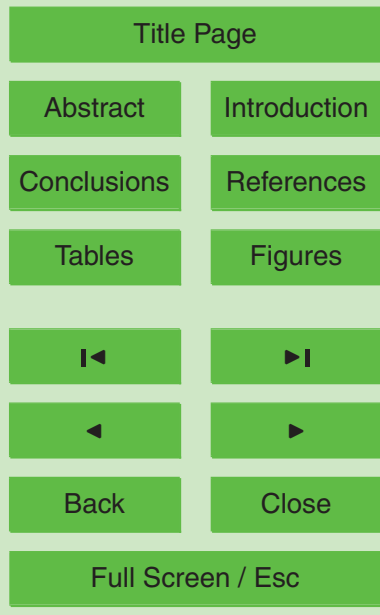

Printer-friendly Version

Interactive Discussion 


\section{Abstract}

Changes in land cover and land use can lead to significant impacts to hydrology by affecting the amount of runoff, soil moisture and groundwater recharge over a range of temporal and spatial scales. However, hydrologic effects of these changes are still an

5 unknown at watershed scale. Moreover, predicting the effects of land cover/use and climate change on hydrological cycle has remained a major challenge. This is because of the complexity and uncertainty of future climate changes making it difficult to predict the consequences. It is against this backdrop that, for sustainable water resources management, assessment of the impacts of land cover/use change on hydrological regime at all scales becomes critical. During this study, we applied the SWAT model to assess the impacts of area hydrology between baseline and alternative scenario (upscaling of rainwater harvesting technologies). Specifically, our overall objective was to quantitatively evaluate the effects of land use changes on watershed hydrology in the upper Ewaso Ngiro North basin in Kenya. This was achieved by estimating hydrological responses under historical land use scenarios obtained from the multi-temporal satellite imageries of 1987, 1995 and 2003. The model performance was found to be relatively good (Nash and Sutcliffe efficient of $70 \%$ ). Stream flow analysis was carried out for different parts of the basin to understand its hydrological responses, especially, the behavior of base flow. The results show a decrease in base flow during 1987-2003 period with decreasing forest, bush and grass covers, which can be attributed to poor natural vegetation emanating mainly from overgrazing and deforestation for agricultural activities. In conclusion, the study clearly shows that, assessment of hydrologic effects of land use changes is critical for a sustainable water resources planning and management of the basin.

\section{HESSD}

$8,2477-2501,2011$

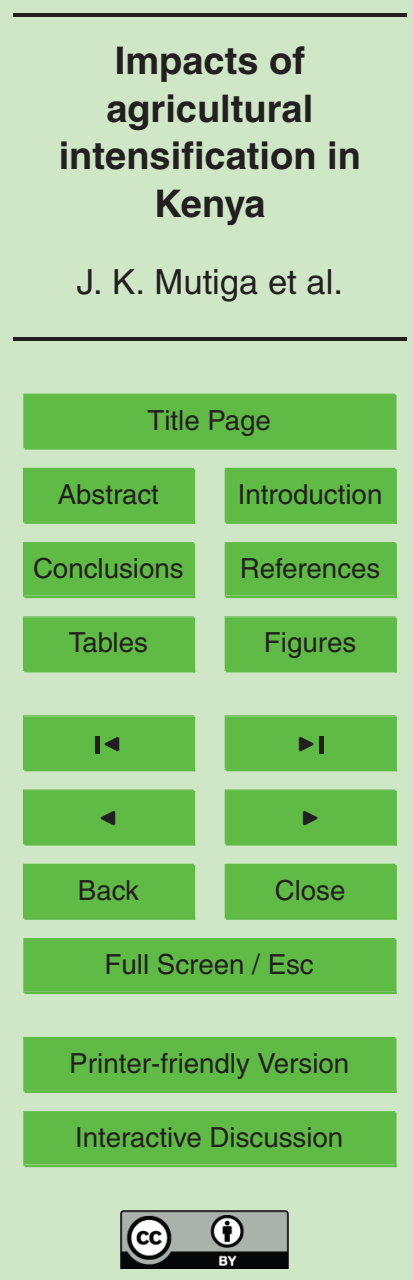




\section{Introduction}

Global water demand for food production for the growing world population is expected to rise and part of this increase will result in escalating water scarcity (Wisser et al., 2009; Rockström et al., 2007). As fresh water resources are limited, the question

5 arises of whether there will be sufficient water per capita available in the 21 st century to fulfill the demand generated by increasing population. Moreover, over exploitation of the useable water resources has already threatened the sustainability of the fresh water availability (Zalewski, 2000).

Studies on water demand for food, environment and industries indicate that more developing countries would experience chronic and physical water shortage by 2025 (Bastiaanssen, 2000). Already some countries mainly in the Middle East and Africa are confronted with water supply shortage (Al-Weshah, 2002). Therefore, the challenge to manage the scarce water resources in a sustainable manner is growing.

Hydrological processes inside river basins are complex due to the combined nature of the natural processes and man made features. Moreover, properties of media forming hydrological systems display a degree of heterogeneity at various scales (Wolski, 1999; Bronstert and Bardossy, 2003). Therefore, attempts to obtain quantitative description of hydrology in river basins must consider these spatial and temporal heterogeneities.

20 Land cover/use changes (LUCs) do alter the hydrological cycle of a catchment by modifying its rainfall, evaporation and runoff, particularly in small catchments (Cao et al., 2006). Furthermore, they can affect the amount of runoff, soil moisture and groundwater recharge over a range of temporal and spatial scales (Calder, 1992; Im et al., 2003). However, predicting the effects of LUCs on hydrological cycle has remained a 25 major challenge (Sivapalan, 2003).

In recent years, different hydrological models have been applied to quantify the effects of land use changes on the hydrological cycle (Fohrer et al., 2001; Lørup et al., 1998; Beven, 1989; Refsgaard, 1997; Chen and Li, 2004; Quilbe et al., 2008).
HESSD

8, 2477-2501, 2011

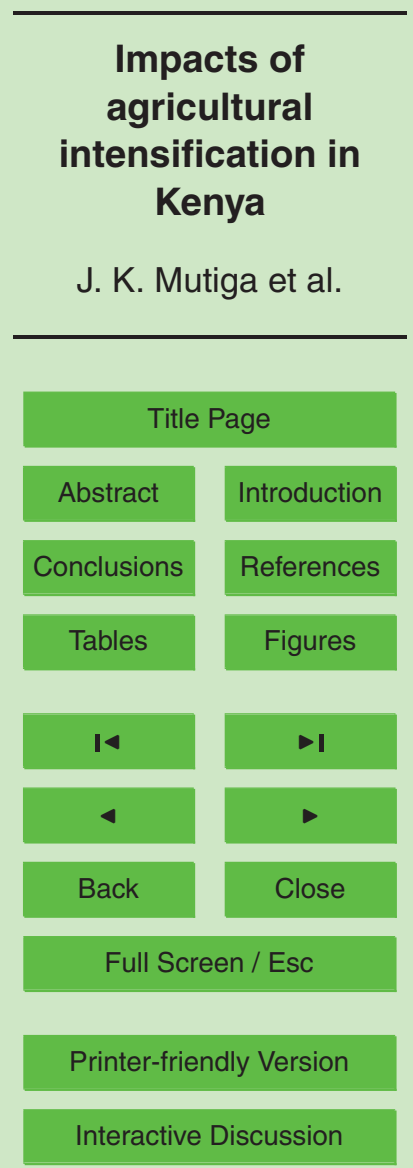

Interactive Discussion 
Generally, hydrological modelling is an attempt to describe the physical processes (canopy interception, evapotransiration, overland flow) controlling the transformation of precipitation to runoff (Al-Sabbagh, 2001). For example, Fohrer et al. (2001) who applied SWAT model on a meso-scale catchment observed that, surface run-off is most 5 susceptible variable to LUCs though its influence is difficult to quantify particularly at large scale with complex interactions.

Nevertheless, recent developments of decision support systems based on geographic information systems (GIS) and distributed hydrological models have provided practical and useful tools to achieve this goal (Fohrer et al., 2001).

10 Land use changes, especially those arising from intensification of rain-fed agriculture, are usually driven by the need to improve agricultural production and hence livelihoods (Ngigi et al., 2008). To enhance productivity of rain-fed agriculture, supplemental small-scale irrigation infrastructure through $\mathrm{RWH}$ is important for increasing evapotranspiration, particularly given growing environmental and social concerns about large 15 scale irrigation projects (de Fraiture et al., 2007) that rely heavily on abstractions from either groundwater or river flows.

Due to the complexity of the climate system and its interactions with the hydrological cycle, it is extremely difficult to detect the causes of climate and land use change that are responsible for changes in the rainfall - runoff relationship (Pfister et al., 2004). Difficulties in predicting these changes can arise from the limit of data quality, the short period of measurements, and the gaps in time series, etc. This makes hydrological models useful tools for extrapolating data in space and time and to simulate the effects of changing climate and land use conditions on the hydrological processes in a river basin.

25 In this study, we applied the soil and water assessment tool (SWAT) model to estimate spatial variations of surface runoff resulting from upscaling of rainwater harvesting $(\mathrm{RWH})$ in the upper Ewaso Ng'iro North basin in Kenya. Impacts were assessed on the area hydrology between baseline and alternative scenario such as upscaling of suitable RWH technologies. Our overall objective however, was to quantitatively evaluate
HESSD

$8,2477-2501,2011$

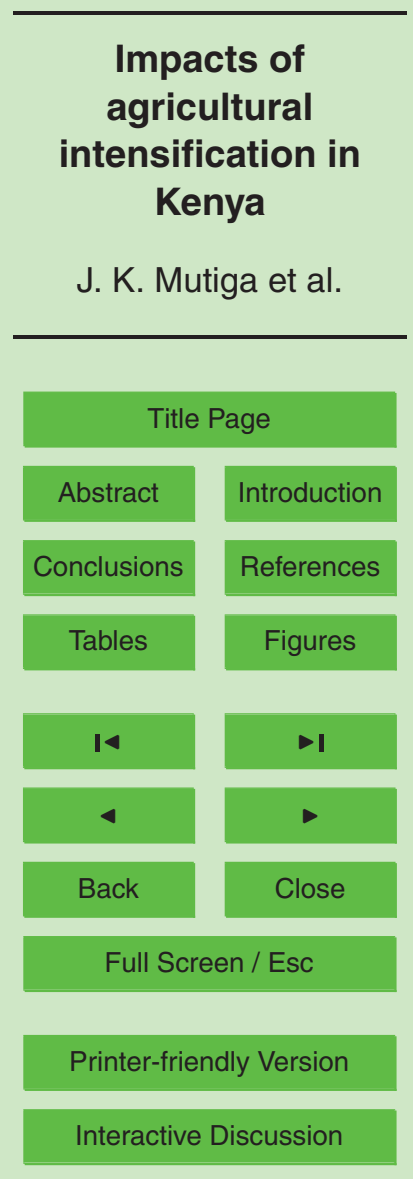

Interactive Discussion 
the effects of land use changes on watershed hydrology of the basin (Fig. 1). This was achieved by estimating hydrological responses under historical land use scenarios obtained from multi-temporal satellite imageries.

\section{Materials and methods}

\subsection{Study area}

The major challenges facing the upper Ewaso Ng'iro North basin include rapidly growing population and degradation of natural resource base resulting to declining land productivity and consequently insecure livelihoods. Farmers migrating from adjacent high agricultural potential districts due to increased pressure on land have caused land 10 use changes particularly in the lower zones from natural vegetation to small scale agriculture, which have led to increased water abstraction and subsequently decreased river flows (Gichuki, 2002).

Land use changes in the basin, and especially from the intensification of rain-fed agriculture, have become inevitable due to increased food demand. Such changes

are bound to have positive socio-economic impacts geared towards improving livelihoods, but may also lead to negative impacts downstream, consequently affecting their livelihoods and natural ecosystems that depend on sustained river flows (Ngigi et al., 2006). Generally, upstream watersheds play an important role on controlling the stream flow regime, and its hydrologic behaviour (water yield and runoff generation) depends mainly on their vegetation cover, soil and geological setting (Tangtham, 1998).

Low rainfall reliability and occurrences of dry spells in the basin are responsible for persistent crop failure in the upper Ewaso $\mathrm{Ng}^{\prime}$ iro North basin. Studies by Ngigi et al. (2006) indicate that, there is $60 \%$ probability of occurrence of below average rainfall and $50-80 \%$ of agricultural droughts in the basin. However, it was also observed that, on-farm storage RWH systems can adequately address major critical water deficits by storing runoff for supplemental irrigation (SIR), thus bridging the dry spell period.
HESSD

$8,2477-2501,2011$

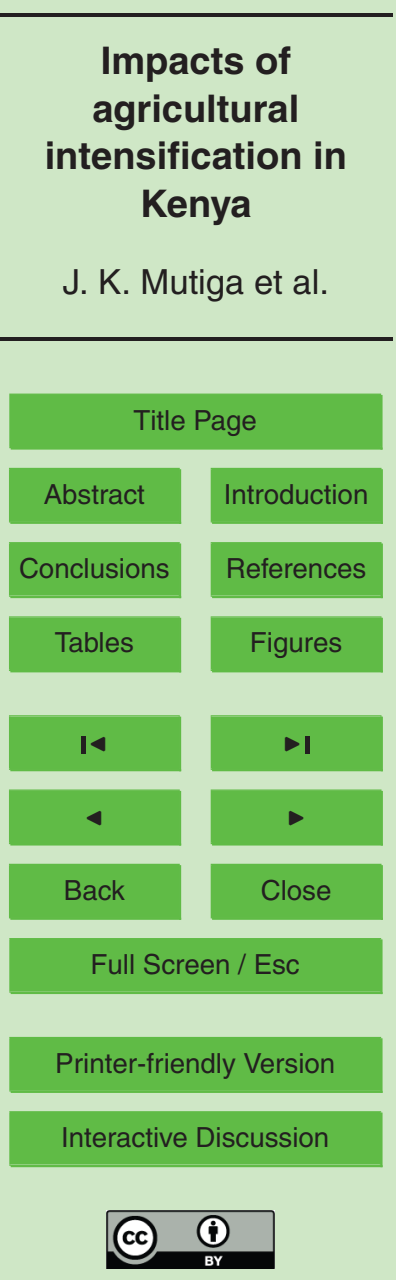


Water demand is continuously increasing in the basin due to population growth and irrigation development. About 60 to $95 \%$ of the available river water in the upper reaches of the basin is abstracted during the dry season with up to about $90 \%$ of the total abstraction being illegal (Kiteme and Gikonyo, 2002; Notter et al., 2007). This has 5 negatively affected downstream populations and natural ecosystems leading to water use conflicts (Mutiga et al., 2010).

However, all is not lost since RWH can play a vital role in easing competition for the scarce water resources and consequently enhance food security. RWH is increasingly being recognized as a viable strategy for improving food production, especially by 10 small-scale farmers in semi-arid environments. Rockström and Falkenmark (2000) observed that RWH can provide the opportunity to maximize soil water holding capacity and mitigate dry spells in order to increase water productivity. Therefore, RWH need to be promoted significantly to enhance their adoption rates.

\subsection{Description of the SWAT model}

15 SWAT is an acronym for Soil and Water Assessment Tool, a river basin model developed originally by the USDA Agricultural Research Service (ARS) and Texas A\&M University that is currently one of the worlds leading spatially distributed hydrological models. The model is a physically based semi-distributed rainfall-runoff model that operates on a daily time step. It comprises of a GIS interface that outlines the sub-basins and stream networks from a Digital Elevation Model (DEM) and calculates daily water balances from meteorological, soil and land-use data (Arnold et al., 1998; Srinivasan et al., 1998). The model has the capability to predict the impact of management on water, sediment and agricultural chemical yields in large basins (Fontaine, 2002). The main components of the model include hydrology, weather, sedimentation, soil tem-

perature, crop growth, nutrients, pesticides and agicultural management. However, fundamental strength of SWAT is the combination of upland and channel processes that are incorporated into one simulation package. The model has been widely used for both agricultural and water resources applications (Gassman et al., 2007).

\section{2}

\section{HESSD}

$8,2477-2501,2011$

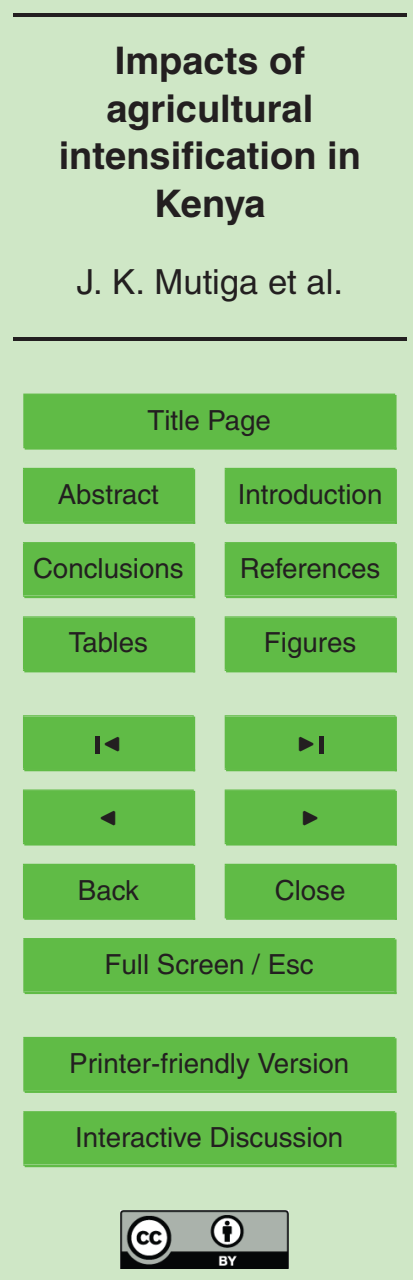


Conceptually, the model divides a catchment into smaller discrete calculation units (hydrological response units - HRUs) for which the spatial variation of the major physical properties are limited, and hydrological processes can be treated as being homogeneous. The total catchment behaviour is a net result of manifold small sub-basins. The 5 model operates on a daily time step, and can be used to predict the impacts of land management practices on water, sediment and agricultural chemicals in catchments (Neitsch et al., 2002; Chaplot, 2004).

The upper Ewaso Ng'iro North basin was subdivided into sub-basins and a river network based on a digital elevation model (DEM). Based on the unique combinations 10 of soil and land use, the sub-basins were further detailed into hydrological response units (HRUs), which are the fundamental units of calculation. In total, 40 sub-basins and $128 \mathrm{HRUs}$ were delineated for the basin.

\subsection{Data requirements}

SWAT model requires detailed spatial and temporal input data, as it is a highly detailed 15 physical model. The most important spatial information used includes Digital Elevation Model (DEM), weather variables, land use, soil properties and land management practices. The DEM, which forms the basis for delineating the catchment boundary, stream network and creates sub-basins, was obtained from the interpolation of $20 \mathrm{~m}$ interval contours. For temporal data, daily rainfall and potential evapotranspiration were used as climatic input data. Rainfall records were collected from five meteorological stations within the basin (Fig. 1) while potential evapotranspiration was calculated by using the FAO Penman-Monteith method (FAO, 1998) which requires air temperature, relative humidity, wind speed, and radiation data.

The soil and land cover/use layers for the basin were used to generate unique com25 binations, each considered as having a homogeneous physical property called Hydrological Response Unit (HRU) which form the fundamental units for modelling. Hence, SWAT was used to distribute the river basin into units with similar characteristics in soil,
HESSD

$8,2477-2501,2011$

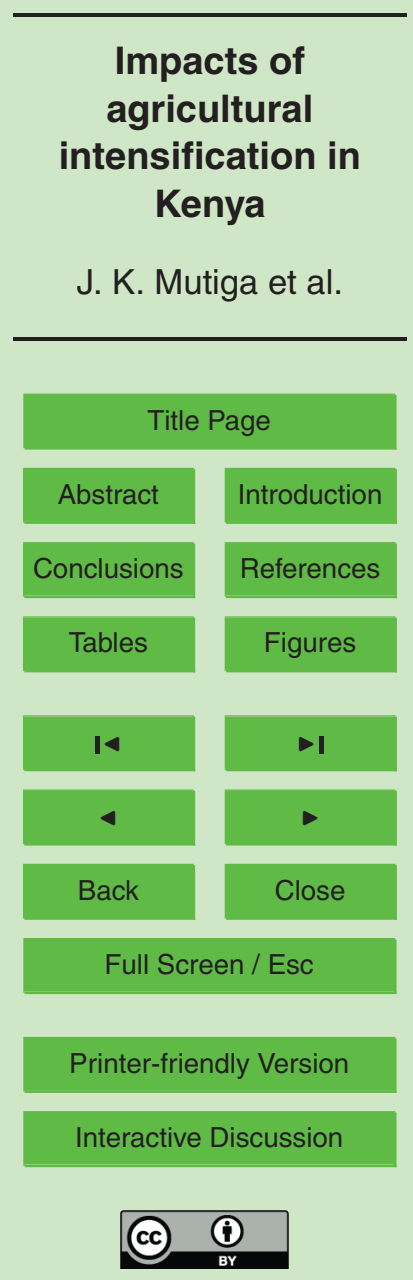


land cover and that are located in the same sub-basin. The water balance for every $\mathrm{HRU}$ was computed on a daily time step.

\subsection{Model calibration and validation}

The SWAT hydrological model was run on a daily time step, with model calibration, val5 idation and analyses computed on a monthly basis for the basin. Calibration was performed manually by varying the ten most sensitive parameters (Table 1) in the model. This process was applied to examine the influence of various model parameters, step by step with an aim of improving simulated results as measured variables may not always be readily available for the area under investigation. The calibration and validation were done using the flow records from 1970 through 1990 for Mt. Kenya sub-basin (Fig. 1), where we had adequate data. The period was split into two periods; 19701980 for calibration and 1980-1990 for validation.

\section{Results and discussions}

\subsection{Model calibration and validation}

15 The initial model runs, after calibration, resulted in reasonable agreement between monthly observed and simulated discharge with a Nash-Sutcliffe efficiency of 0.75 indicating that the model performed well and could therefore be applied for discharge prediction. In general, model performance efficiency, determines how well the probability distributions of simulated and observed data fit each other.

20 The performance efficiency $\left(R^{2}\right)$ value for simulated versus observed daily stream flow for the basin was 0.75 for the calibration period and 0.70 for the validation period (Fig. 2). Visual comparison of simulated and observed stream flow during the calibration period shows that the model performed well in terms of the rainfall and runoff relationships.
HESSD

8, 2477-2501, 2011

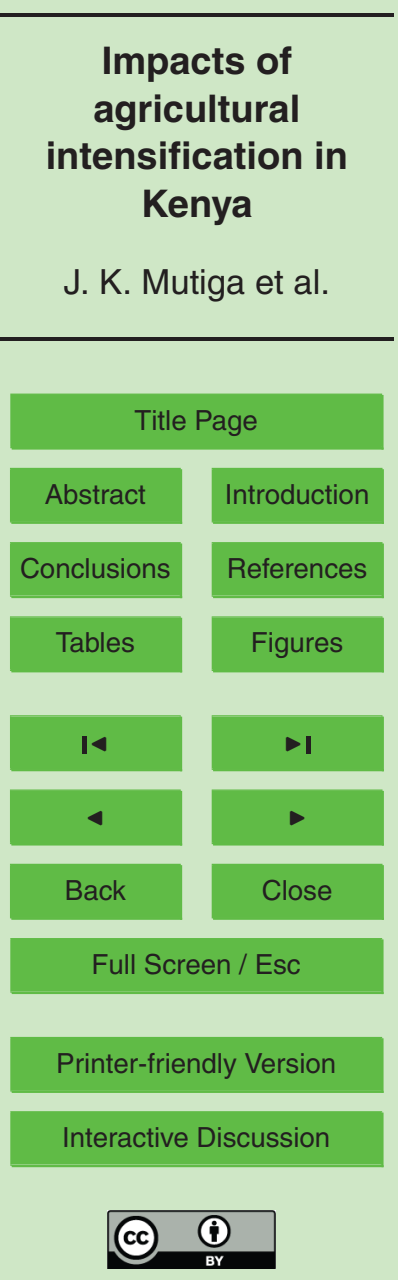




\subsection{Model simulations}

The SWAT model divides contributions to river flow into three categories; surface overland flow, lateral flow (quick flow within the upper soil profile) and groundwater flow (return flow from shallow aquifers), Table 1.

5 Major components of the hydrologic budget were simulated to determine the impacts of proposed land management (RWH) and LUC changes. This was done for 20032015 period. It was assumed that during the base year (2003) there is no RWH, and that it would be implemented sufficiently to meet crop requirements by 2015 . The soil conservation service curve number (SCS, CN) approach and Penman-Montheith 10 methods were used to calculate runoff and potential evapotranspiration respectively (Table 1).

\subsection{Land cover/use changes and population}

Land cover/use types for the three time periods were obtained from classification of multi-spectral landsat images of 1987, 1995 and 2003, each with a spatial resolution 15 of $30 \mathrm{~m}$. Proportional changes in land use during the study period were determined by visually comparing classification results of multi-temporal images. Four main land cover/use types (forest, grassland, bushland, and cropland) were identified in the upper Ewaso Ng'iro basin and used for SWAT simulations. However, it was observed that the upper catchments experienced the highest forest cover loss due to encroachment from 20 people migrating from the neighbouring high potential areas with dense population (Kohler, 1987; Wiesmann, 1998). This resulted in catchments deterioration, making them prone to erosion and flooding. The population in the basin grew from 250000 to about 650000 in 1987 and 2003 respectively (more than double).

The dominant land cover types in the area include forest, grassland, bareland and 25 cropland (Table 2). Results obtained show that, forest cover decreased by about $7 \%$ between 1987 and 2003. Similarly bushland and grassland areas reduced drastically during the same period while bareland increased. The decrease could be associated

HESSD

$8,2477-2501,2011$

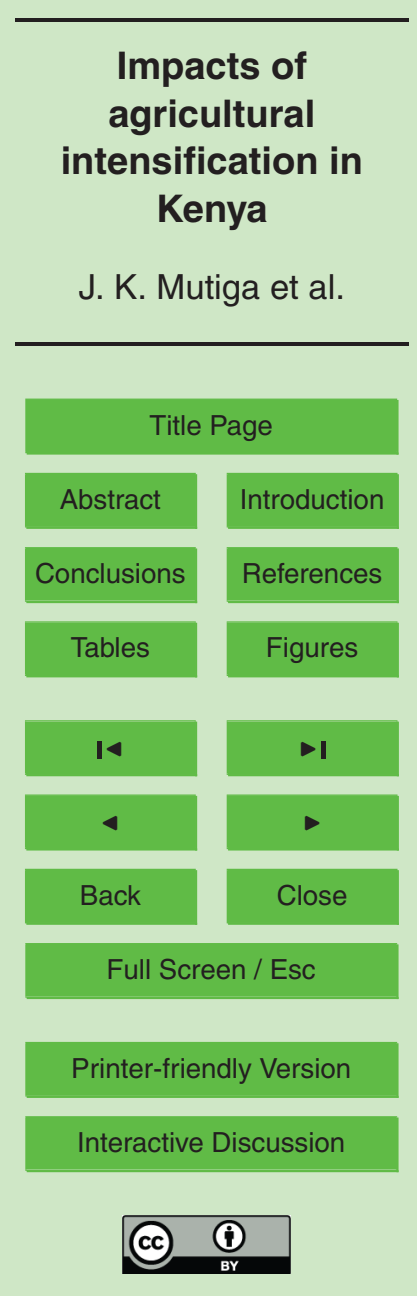


with the need to clear more land for agricultural activities to feed the growing population as indicated by an increase in cropland. However, the increase in bareland witnessed over the same period could be associated to overexploitation of the soils through continuous poor farming practices with minimum soil nutrient in the area in addition to overgrazing. There was a $100 \%$ increase in urban area in the same period.

\subsection{Runoff generation}

Surface runoff generally occurs when the rate of water application to the ground surface exceeds the rate of infiltration. SCS curve number method was used to estimate surface runoff. Based on land use change scenarios, model parameters (Table 1) were 10 recalculated and the model was re-run to deliver the modified flows. Figure 3 gives the simulated flow hydrographs for the three years (1987, 1995 and 2003) and land cover/use scenarios in the catchment. Analysis from running the model under different land cover/uses, revealed that runoff significantly increased (Table 3 ) leading to a decrease in evapotranspiration (ET) in relation to rainfall.

15 It was observed that surface runoff constitutes about $20 \%$ on average of the annual water balance in the basin with a higher component being converted to evapotranpiration (about $60 \%$ on average) leading to less groundwater recharge and consequently less water availability (Table 3 ). This observation tends to agree with the findings of Rockström (1999) on how rainfall is partitioned in the dry areas of SSA (10-25\%, runoff 20 and $45-80 \%$, evapotranpiration). Further, the results also revealed that upscaling of $\mathrm{RWH}$ increased base flow by about $5 \%$ and reduced surface runoff by $2 \%$ with no significant effects in the downstream areas. The principal areas with relatively high runoff generation include the headwaters in the Mt. Kenya and the Aberdare ranges.

Table 3, shows the average annual values of modelled hydrological components and 25 changes attributed to land cover/use changes over the last 15-yr period in the basin. The results indicate that there were slight increases in surface runoff and lateral flow as a response to the land cover/use change. The percent increase in surface runoff over the 15-yr period (1987-2003) was about $4 \%$ per year while shallow ground water
HESSD

$8,2477-2501,2011$

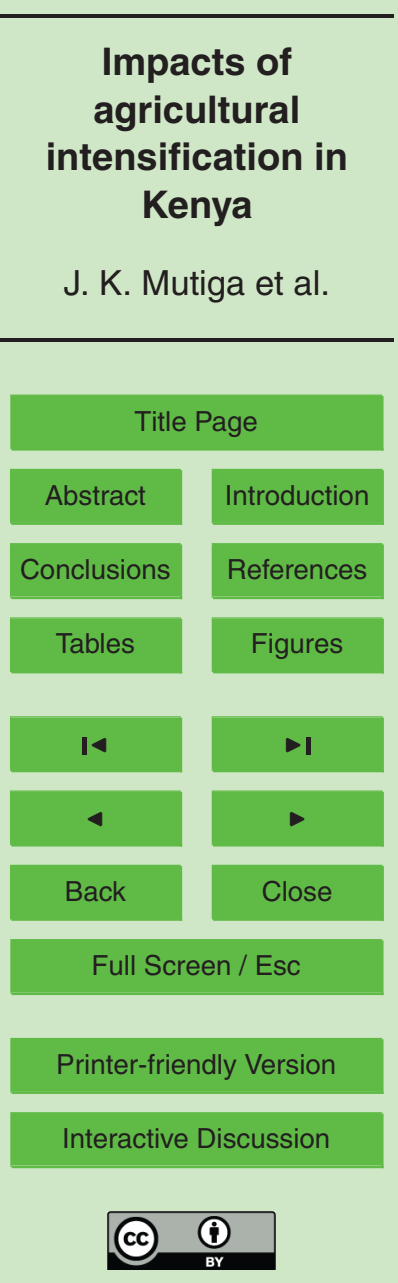


flow decreased by about $1 \%$ per year (Table 3 ). This situation was primarily due to the changes in land cover/use experienced during this period (Table 2).

Nortcliff et al. (1990) observed that major changes in runoff occur between 0 to $30 \%$ vegetation cover, with higher vegetation cover having relatively smaller impacts. This 5 tends to agree with the findings of the current study which show that the observed surface runoff increased gradually during 1987-2003 period (Table 3) with decreasing forest, grassland and bushland covers (Table 2). This can be attributed to poor natural vegetation resulting from overgrazing and deforestation for agricultural activities. This is because, infiltrated water reduces with decreasing vegetation cover.

10 Expansion in cropland resulted in higher surface runoff and consequently higher annual water yields (Table 3). Since an increased water yield percolates through welldrained soils, the primary implications include flooding in the downstream areas of the basin, and if this flood water can be diverted and stored to supplement irrigation activities, could reduce the downstream impacts significantly.

\subsection{Downstream impacts of upscaling RWH}

The results revealed that there are insignificant effects on downstream flow (Fig. 3) resulting from the upscaling suitable $\mathrm{RWH}$ technologies in the upstream part of the basin. The annual total water yields, quick flow and base flow decreased moderately in the two scenarios when compared with flow at the current land cover/use (2003). The flow duration curves shows the temporal variation of flow over the three periods which could also be related to climate variability in addition to LUCs.

Land cover/use changes, especially those emanating from the intensification of rainfed agriculture within the basin are inevitable due to the need to meet increasing food demand. Such changes could have either, positive socio-economic impacts such as those improving yields and hence livelihoods, but could also lead to negative impacts downstream, such as reduced water availability thus affecting both people and the natural ecosystems. Figure 4, gives the simulated flow hydrographs for the three land cover/use scenarios of the basin during 1987-2003 periods. Moreover, it was noted

HESSD

8, 2477-2501, 2011

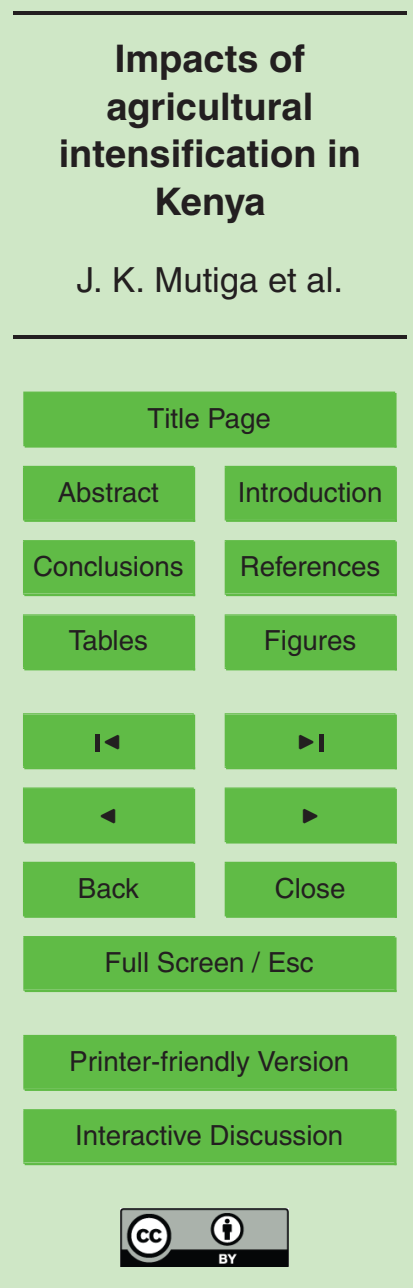


that the upstream part of the catchment, played an important role of controlling stream flow with its hydrologic behaviour (water yield and runoff generation) depending mainly on the vegetation conditions agreeing with the observations made by Tangtham (1998).

Furthermore, the results from this study indicate that an increase in ET as a result

5 of intensifying agricultural activities using $\mathrm{RWH}$ technologies led to a decrease in the amount of water penetrating into the soil profile to replenish the shallow groundwater storage during the wet season. This change caused a reduced contribution of groundwater to the river flow and hence the overall discharge.

Monthly average surface runoff tends to follow the rainfall pattern with higher values 10 being observed when rainfall amounts are also high, clearly distinguishing between the two rainfall peaks (April-May and October-November) in the basin with relatively low values during the dry seasons (January-February and August-September).

\section{Conclusions}

SWAT model was applied to investigate the watershed-scale hydrologic impacts of land 15 use changes within a $800 \mathrm{~km}^{2}$ watershed. Simulated stream flow at the watershed outlet was found to be close to observed values with respect to low flow, and partly peak flows for the study period. The model however often underestimated at some rainfall events. This could be due to the poor quality of input data. Nevertheless, a good agreement was also observed between simulated and the observed total runoff 20 volumes during the simulation period.

Moreover, the results obtained also show that basin hydrology was found to be relatively sensitive to changes in land cover/use attributes, with a general pattern of increasing surface runoff with a decrease in forest, bushes and grasses with a subsequent decrease in evapotranspiration. However, intensification of rain-fed agriculture 25 particularly in the upstream of the catchment does not significantly lower water availability in its downstream. Further, it was noted that the upstream part of the catchment,

\section{HESSD}

$8,2477-2501,2011$

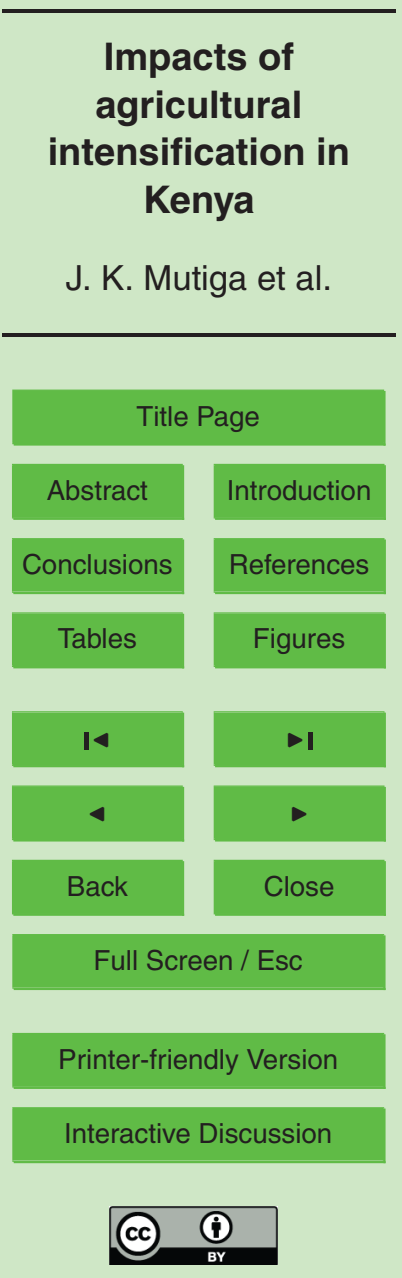


play an important role of controlling stream flow with its hydrologic behaviour (water yield and runoff generation) depending mainly on the vegetation conditions agreeing with the observations made by Tangtham (1998).

The performance of the model was assessed using the Nash and Sutcliffe efficient 5 model performance evaluation criteria, and after verification, the model was applied for different scenario analyses (status quo and upscaling of $\mathrm{RWH}$ ). Simulation of different scenarios demonstrates the implications of increased evapotranspiration (due to RWH upscaling) particularly to the contribution of groundwater to river discharge. Confidence can therefore be placed in asserting that irrespective of the level of future 10 changes in $\mathrm{RWH}$, the change in proportion of runoff that contributes to Ewaso $\mathrm{Ng}$ 'iro river discharge through groundwater flows is insignificant and does therefore not affect the downstream flow significantly as a result of increasing ET.

The results also revealed that upscaling of $\mathrm{RWH}$ increased base flow by about $5 \%$ and reduced surface runoff by $2 \%$ with no significant effects in the downstream areas. In conclusion, assessment of the hydrologic effects of land cover/use changes is crucial for water resources development and management in the basin. Rapid population growth in addition to the effects of climate change has adversely impacted on the already limited resources (mainly water, arable land and pasture) leading to overwhelming conflicts over their use and management.

Smallholder agro-pastoralists have become the main agents of resource degradation in the recent past as they engage themselves in survival and coping strategies that are incompatible with prevailing ecological conditions in the basin. In addition, unregulated land subdivision has resulted in small and unviable land parcels that cannot support any meaningful livelihood. All these combined, have led to resource use conflicts especially in the dry areas of the basin (lowlands). This situation has been escalated by the increasing effects of climate change. Resource use conflicts in the Upper Ewaso Ng'iro basin have now become as unpredictable as the weather over the past two decades with violence reaching to unexpected level in 2007/2008 period. This consequently resulted in loss of human lives and property worth millions of shillings as witnessed
HESSD

8, 2477-2501, 2011

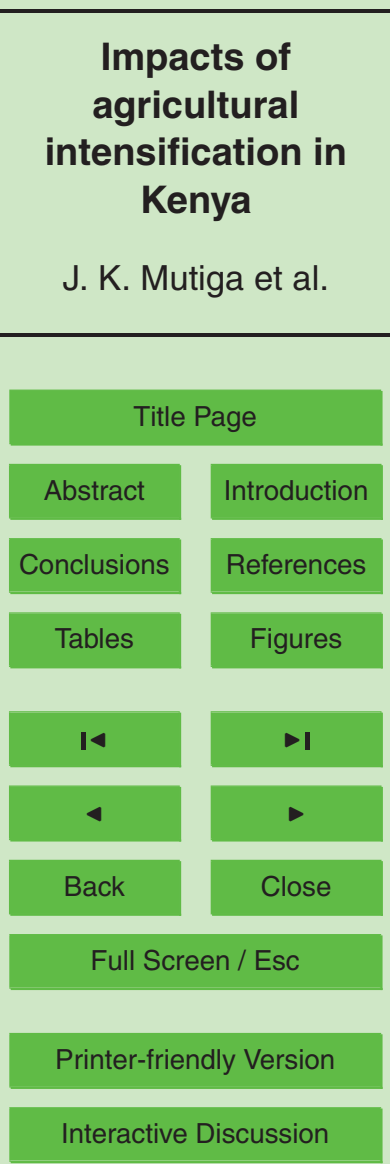

Interactive Discussion 
during the post election violence not only in the basin, but also in most parts of the country (Kenya).

To minimize these effects, innovative natural resources (water and pasture) management remains crucial calling for formulation of policies in relation to natural resources 5 use and management that provide efficient mechanisms to address the situation while ensuring their sustainability. From the findings of this study, upscaling of RWH could play this critical role by providing more water for use especially during the dry season when the user conflicts are at their peak.

Acknowledgements. The work reported here is part of the on going research on "Planning of 10 System Innovations in Watersheds: Spatial Mapping of Environmental and Hydrological Determinants in Ewaso Ngiro North River Basin, Kenya", being funded by the Dutch government under the Netherlands Fellowship Programme and Faculty of Geo-Information Science and Earth Observation (ITC) of the University of Twente.

The authors wish to thank ITC, for the immense support both financially and morally accorded during the implementation of this study. Many appreciations are also extended to Director of Centre for Training and Integrated Research for ASAL Development (CETRAD), based in Nanyuki, Kenya for providing with the necessary spatial data sets (Meteorological and biophysical spatial) for this study.

\section{HESSD}

8, 2477-2501, 2011

\section{Impacts of agricultural intensification in Kenya}

J. K. Mutiga et al.

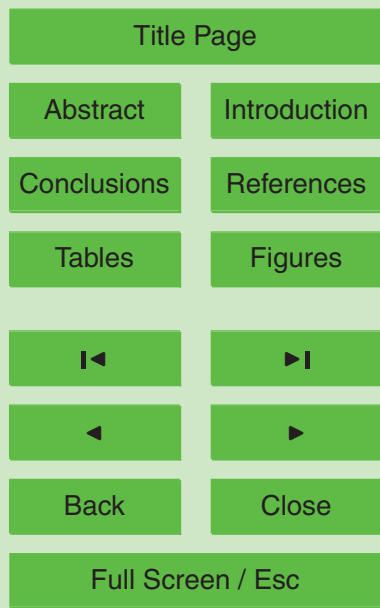

Printer-friendly Version

Interactive Discussion 


\section{References}

Allen, R. G., Pereira L. S., Raes, D., and Smith, M.: Crop Evapotranspiration, Guidelines for Computing Crop Water Requirements, FAO Irrigation and Drainage Paper 56, Food and Agriculture Organization of the United Nations, Rome, Italy, 1998.

5 Al-Sabbagh, M.: Surface runoff modeling using GIS and remote sensing, MSc. Thesis, International Institute for Aerospace Survey and Earth Science, Enschede, The Netherlands, 2001.

Al-Weshah, A.: The role of UNESCO in sustainable water resources management in the Arab World, Desalination, 152, 1-13, 2002.

10 Arnold, J. G., Srinivasan, R., Muttiah, R. S., and Williams, J. R.: Large area hydrologic modeling and asssement. Part I: Model development, J. Am. Water Resour. As., 3410, 73-89, 1998.

Bastiaanssen, W. G. M.: SEBAL based sensible and latent heat flux in the irrigated Gediz Basin, Turkey, J. Hydrol., 229, 87-100, 2000.

Beven, K. J.: Changing ideas in hydrology: the case of physically based models, J. Hydrol., 105, 157-172, 1989.

Bronstert, A. and Bardossy, A.: Uncertainty of runoff modelling at the hill slope scale due to temporal variations of rainfall intensity, Phys. Chem. Earth, 28, 283-288, 2003.

Calder, I. R.: Hydrologic effects of land use change, in: Handbook of hydrology, edited by: Maidment, D. R., McGraw-Hill, New York, USA, 1992.

20 Cao, W., Bowden, B. W., and Davie, T.: Multi-variable and multi-site calibration and validation of SWAT in a large mountainous catchment with high spatial variability, Hydrol Proc., 20, 1057-1073, 2006.

Chaplot, V., Saleh, A., and Jaynes, D. B.: Predicting water, sediment and NO3-N loads under scenarios of land-use and management practices in a flat watershed, Water Air Soil Poll., 154, 271-293, 2004.

Chen, J. F. and Li, X. B.: Simulation of hydrological response to land-cover changes, J. Appl. Ecol., 15, 5, 833-836, 2004 (in Chinese).

Chow, V. T., Maidment, D. R., and Mays, L. W.: Applied Hydrology, McGraw-Hill, New York, USA, 1988.

30 L. J. Hanjra, M. A., Hoogeveen, J., Huber-Lee, A., and Karlberg, L.: Looking ahead to 2050: scenarios of alternative investment approaches, in: Comprehensive Assessment of

HESSD

8, 2477-2501, 2011

\section{Impacts of \\ agricultural \\ intensification in \\ Kenya}

J. K. Mutiga et al.

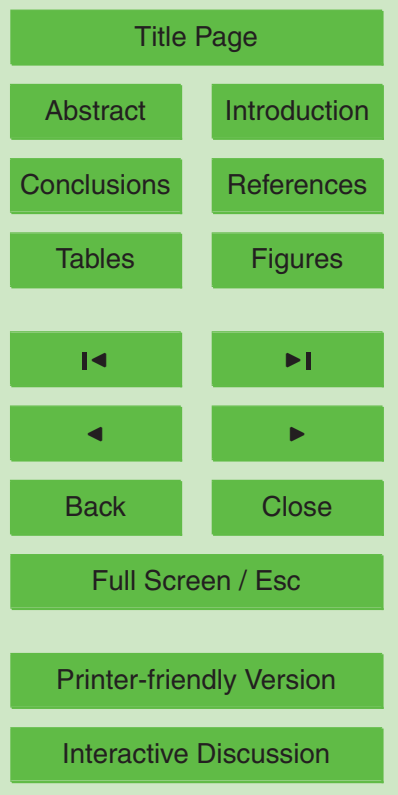


Water Management in Agriculture. Water for Food, Water for Life, edited by: Molden, D., Earthscan/International Water Management Institute, London/Colombo, Chapter 3, 91-145, 2007.

FAO: Crop evapotranspiration, FAO irrigation and drainage, Paper No. 56, Rome, 1998.

5 Fohrer, N., Haverkamp, S., Eckhardt, K., and Frede, H. G.: Hydrologic response to land use changes on the catchment scale, Phys. Chem. Earth Pt. B, 26(7-8), 577-582, 2001.

Fontaine, T. A., Cruickshank, T. S., Arnold J. G., and Hotchkiss, R. H.: Development of snowfall snowmelt routine for mountainous terrain for the soil and water assessment tool (SWAT), J. Hydrol., 262, 209-223, 2002.

10 Gassman, P. W., Reyes, M. R., Green, C. H., and Arnold, J. G.: The soil and water assessment tool: Historical development, applications and future research directions, T. ASABE., 50, 1211-1250, 2007.

Gichuki, F. N.: Water scarcity and conflicts: A case study of the Upper Ewaso Ng'iro North Basin, in: The changing face of irrigation in Kenya: Opportunities for anticipating change in Eastern and Southern Africa edited by: Blank, H. G., Mutero C. M., and Murray-Rust, H., IWMI, Colombo, Sri Lanka, 113-134, 2002.

Im, S., Brannan, K. M., and Mostaghimi, S.: Simulating hydrologic and water quality impacts on an urbanizing watershed, J. Am. Water Resour Assoc., 39, 6, 1465-1479, 2003.

Kiteme, B. P. and Gikonyo, J.: Preventing and resolving water use conflicts in the Mount Kenya highland-lowland system through water users associations, Mt. Res. Dev., 22, 4, 332-337, 2002.

Kohler, T.: Land-use in Transition. African Studies Series A5, Berne, Switzerland, Geographica Bernensia, 1987.

Lørup, J. K., Refsgaard, J. C., and Mazvimavi, D.: Assessing the effect of land use change on catchment runoff by combined use of statistical tests and hydrological modeling: case studies from Zimbabwe, J. Hydrol., 205, 147-163, 1998.

Mutiga, J. K., Su, Z. and Woldai, T.: Using satellite remote sensing to assess evapotranspiration: Case study of the Upper Ewaso Ng'iro North Basin, Kenya, Int. J. Appl. Earth Observ. Geoinform, 12, 100-108, 2010.

30 Neitsch, S. L., Arnold, J. G., Kiniry, J. R., and Williams, J. R.: Soil and Water ssessment Tool Theoretical Documentation, Version 2000 (Draft), Blackland Research Center, Texas Agricultural Experiment Station, Temple, Texas, 2002.

Ngigi, S. N., Savenije, H. H. G., Rockström, J., and Gachene, C. K.: Hydro-economic evaluation
HESSD

$8,2477-2501,2011$

\section{Impacts of \\ agricultural \\ intensification in \\ Kenya}

J. K. Mutiga et al.

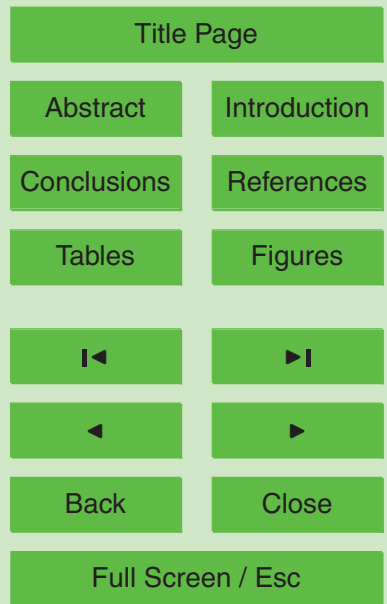

Printer-friendly Version

Interactive Discussion 
of rainwater harvesting and management technologies: farmers' investment options and risks in semi-arid Laikipia district of Kenya, Phys. Chem. Earth, 30(11-16), 772-782, 2005.

Ngigi, S. N., Rockström, J., and Savenije, H. H. G.: Assessment of rainwater retention in agricultural land and crop yield increase due to conservation tillage in Ewaso Ng'iro river basin, Kenya, Phys. Chem. Earth, Parts A/B/C, 31(15-16), 910-918, 2006.

Ngigi, S. N., Savenije, H. H. J., and Gichuki, F. N.: Hydrological Impacts of Food Storage on Irrigation Water Abstraction in upper Ewaso Ng'iro river Basin, Kenya, Water Resour. Manag., 22, 1859-1879, 2008.

Notter, B., MacMillan, L., Viviroli, D., Weingartner, R., and Liniger, H. P.: Impacts of environmental change on water resources in the Mt. Kenya region, J. Hydrol., 343(3-4), 266-278, 2007.

Nortcliff, S., Ross, S. M., and Thornes, J. B.: Soil moisture, runoff and sediment yield from differentially cleared tropical forest plots, in: Vegetation and erosion, edited by: Thornes, J. B., John Wiley, UK, 1990.

Pfister, L., Kwadijk, J., Musy, A., Bronstertd, A., and Hoffmann, L.: Climate change, land use change and runoff prediction in the Rhine-Meuse basins, River Res. Appl., 20, 3, 229-24, 2004.

Refsgaard, J. C.: Parameterisation, calibration and validation of distributed hydrological models, J. Hydrol., 198, 69-97, 1997.

20 Rockström, J.: On-farm green water estimates as a tool for increased food production in water scarce regions, Phys. Chem. Earth (B), 24, 4, 375-383, 1999.

Rockström, J. and M. Falkenmark: Semi-arid crop production from a hydrological perspective: Gap between potential and actual yields, Crit. Rev. Plant Sci., 19, 4, 319-346, 2000.

Rockström, J., Lannerstad, M., and Falkenmark, M.: Assessing the water challenge of a new green revolution in developing countries, P. Natl. Acad. Sci. USA, 104, 15, 6253-6260, 2007.

Soil Conservation Service Engineering Division (SCS): Urban hydrology for small watersheds, US Department of Agriculture, Technical Release, 55, 1986.

Sivapalan, M.: Prediction in ungauged basins: a grand challenge for theoretical hydrology, Hydrol Proc., 17, 3163-70, 2003.

30 Sirinivasan, R., Ramanarayanan, T. S., Arnold, J. G., and Bednarz, S. T.: Large area hydrologic modelling and assessment, Part 2: Model application, J. Am. Water Res. Ass., 34(1), 91102, 1998.

Tangtham, N.: Hydrological roles of the highland watersheds in Thailand, in: Highland ecosys-
HESSD

$8,2477-2501,2011$

\section{Impacts of \\ agricultural \\ intensification in \\ Kenya}

J. K. Mutiga et al.

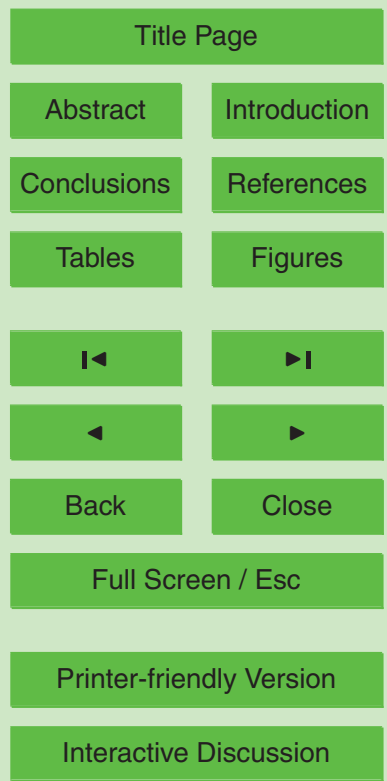


tem management, Proceedings of the International Symposium on Highland Ecosystem Management, edited by: Thaiusa, B., Traymor, C., and Thammincha, S., Angkhang Project Foundation, Chiang Mai, Thailand, 26-31 May 1998, 1998.

Quilbé, R., Rousseau, A. N., Moquet, J.-S., Savary, S., Ricard, S., and Garbouj, M. S.: 5 Hydrological responses of a watershed to historical land use evolution and future land use scenarios under climate change conditions, Hydrol. Earth Syst. Sci., 12, 101-110, doi:10.5194/hess-12-101-2008, 2008.

Wiesmann, U.: Sustainable Regional Development in Rural Africa: Conceptual Framework and Case Studies from Kenya, African Studies 14, Berne, Switzerland, Geographica Bernensia, 1998.

Wisser, D., Fekete, B. M., Vörösmarty, C. J., and Schumann, A. H.: Reconstructing 20th century global hydrography: a contribution to the Global Terrestrial Network- Hydrology (GTN-H), Hydrol. Earth Syst. Sci., 14, 1-24, doi:10.5194/hess-14-1-2010, 2010.

Wolski, P.: Application of reservoir modelling to hydrotopes identified by remote sensing, PhD 15 Thesis, International Institute for Aerospace Survey and Earth Science, Enschede, The Netherlands, 1999.

Zalewski, M.: Ecohydrology - the scientific background to use ecosystem properties as management tools toward sustainability of water resources, Ecol. Eng., 16, 1-8, 2000.

Ziegler, A. D., Giambelluca, T. W., Tran, L. T., Vana, T. T., Nullet, M. A., Fox, J., Vien T. D., tation in mountainous northern Vietnam: evidence of accelerated overland flow generation, J. Hydrol., 287(1-4), 124-146, 2004.

\section{HESSD}

8, 2477-2501, 2011

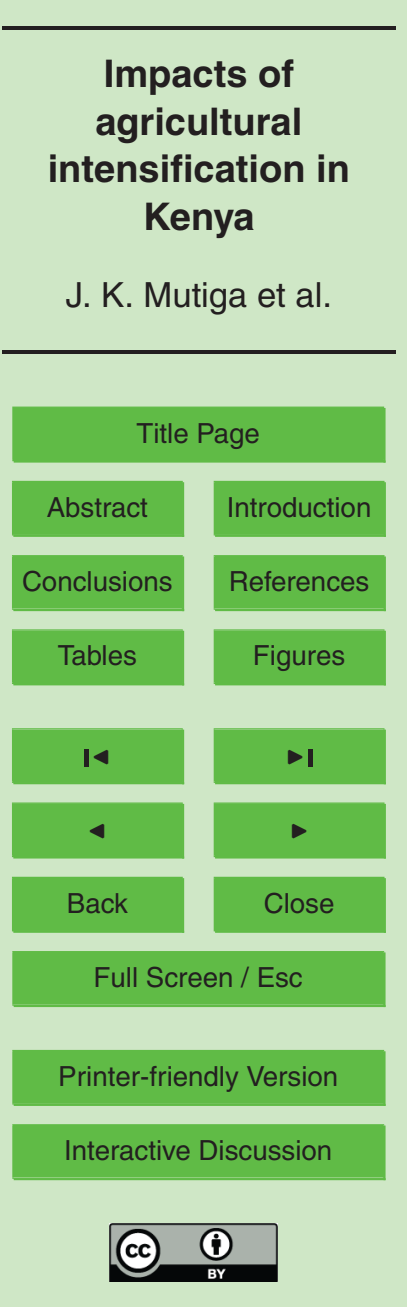




\section{HESSD}

8, 2477-2501, 2011

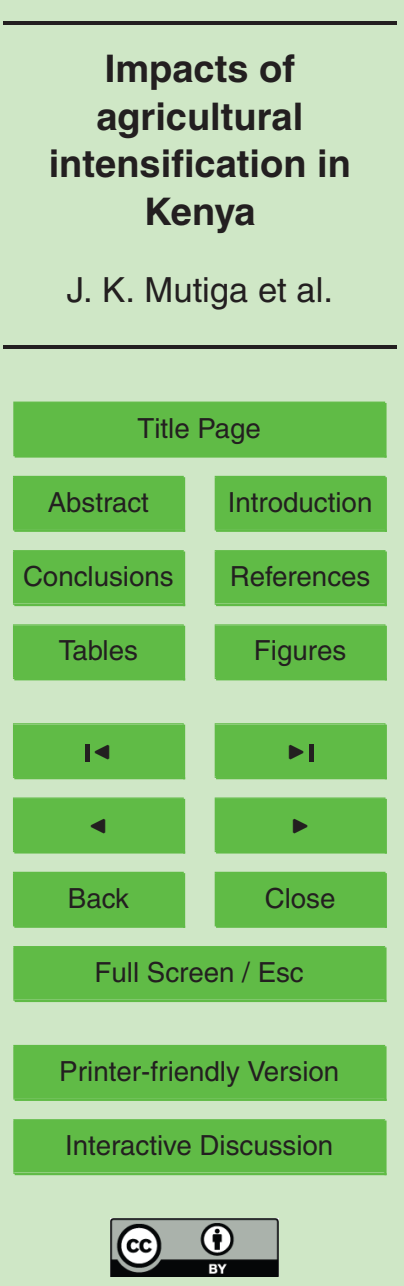

\begin{tabular}{ll}
\hline SWAT Parameter & Parameter Description \\
\hline CN2 & Curve number \\
SURLAG & Surface Runoff lag coefficient \\
SOL_K & Soil Conductivity \\
SOL_AWC & Soil Water Capacity \\
EPCO & Plant Evaporation compensation factor \\
ESCO & Soil Evaporation coefficient \\
GW_REVAP & Groundwater "revap" coefficient \\
REVAPMN & Threshold depth of water in shallow aquifer \\
GW_DELAY & Groundwater Delay \\
ALFA_BF & Base flow alpha factor \\
\hline
\end{tabular}




\section{HESSD}

8, 2477-2501, 2011

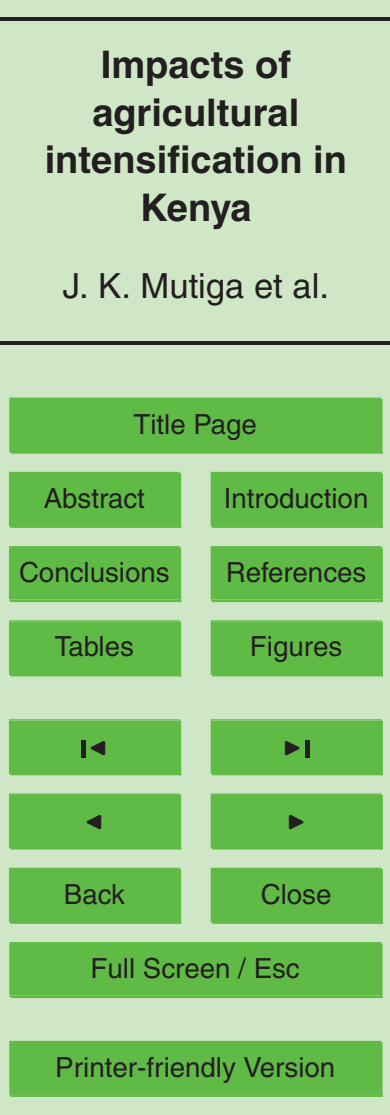

Interactive Discussion 


\section{HESSD}

8, 2477-2501, 2011

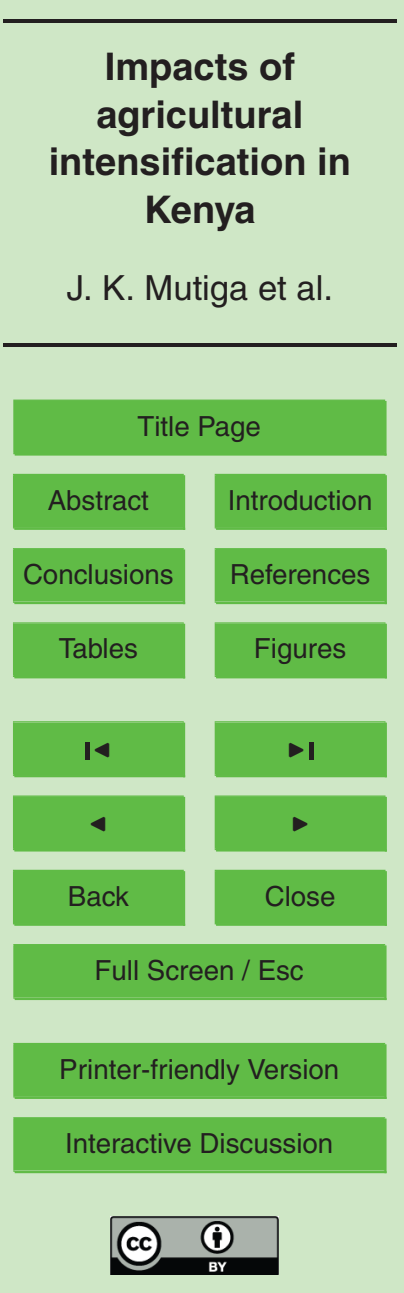

\begin{tabular}{lrrrr}
\hline & 1987 & 1995 & 2003 & RWH \\
\hline Precipitation & $\sim 760$ & $\sim 920$ & $\sim 940$ & $\sim 940$ \\
Surface runoff & $\sim 143$ & $\sim 212$ & $\sim 224$ & $\sim 210$ \\
Lateral soil flow & 24 & 27 & 28 & 25 \\
Shallow GW flow & 62 & 56 & 53 & 55 \\
REVAP & 64 & 62 & 63 & 65 \\
Deep Aquifer Recharge & 12 & 13 & 14 & 16 \\
Total aquifer recharge & 126 & 140 & 146 & 152 \\
Total water yield & $\sim 260$ & $\sim 354$ & $\sim 380$ & $\sim 348$ \\
Soil percolation & 64 & 58 & 60 & 73 \\
Evapotranspiration & $\sim 480$ & $\sim 542$ & $\sim 545$ & $\sim 592$ \\
Transmission losses & $\sim 26$ & $\sim 29$ & $\sim 33$ & $\sim 21$ \\
\hline
\end{tabular}




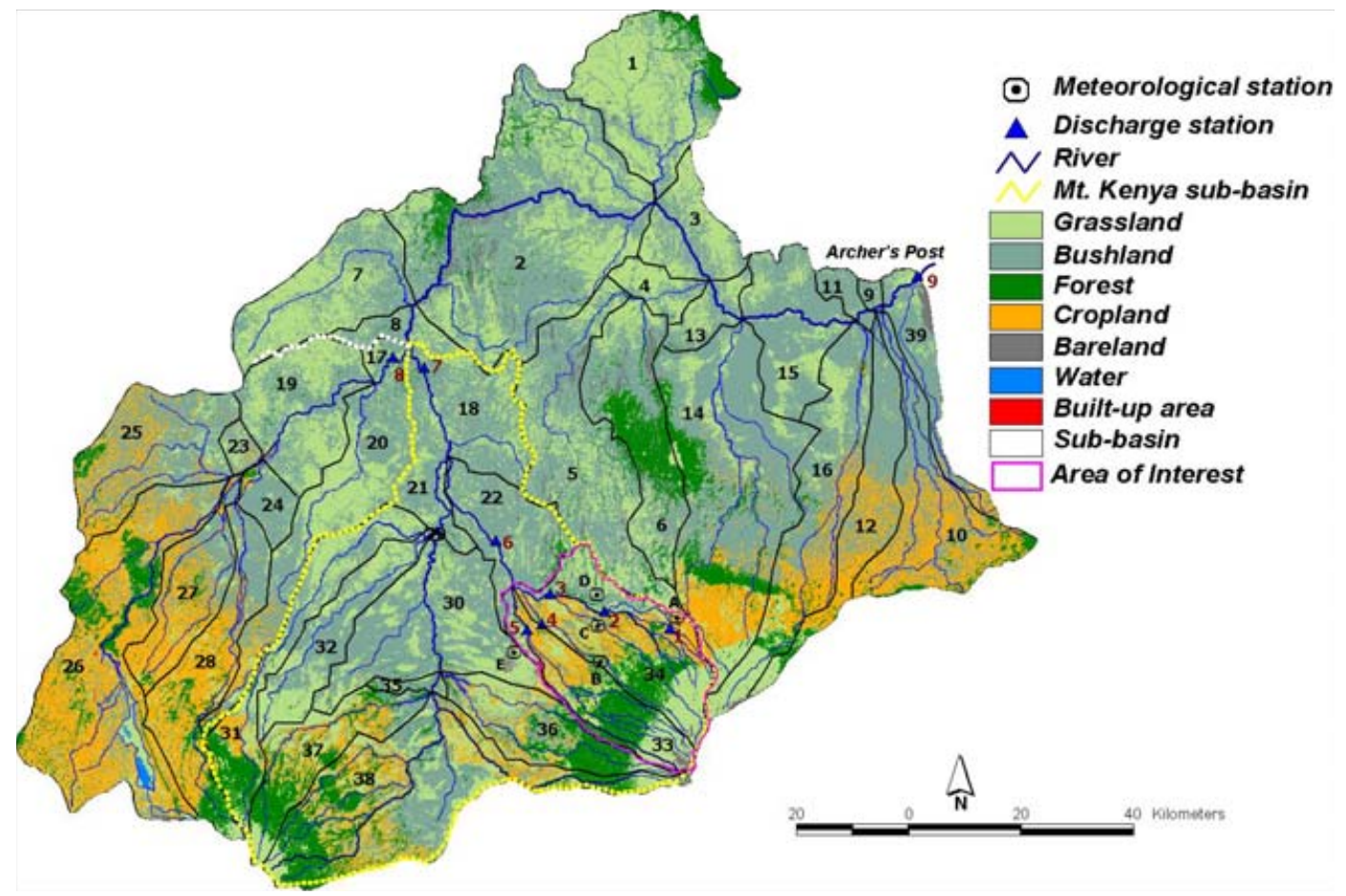

Fig. 1. SWAT model configured for the upper Ewaso Ng'iro North Basin, Kenya with 1-9 discharge gauging stations.

\section{HESSD}

8, 2477-2501, 2011

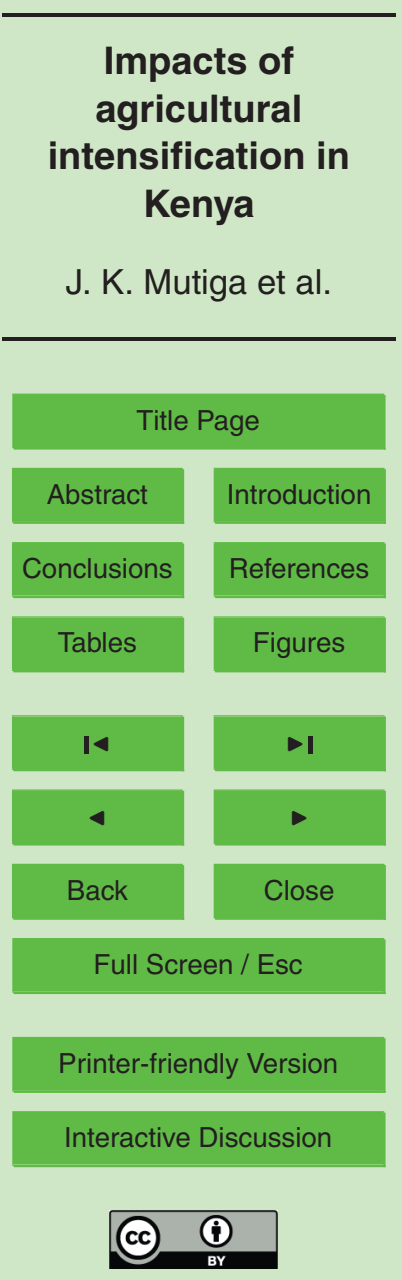




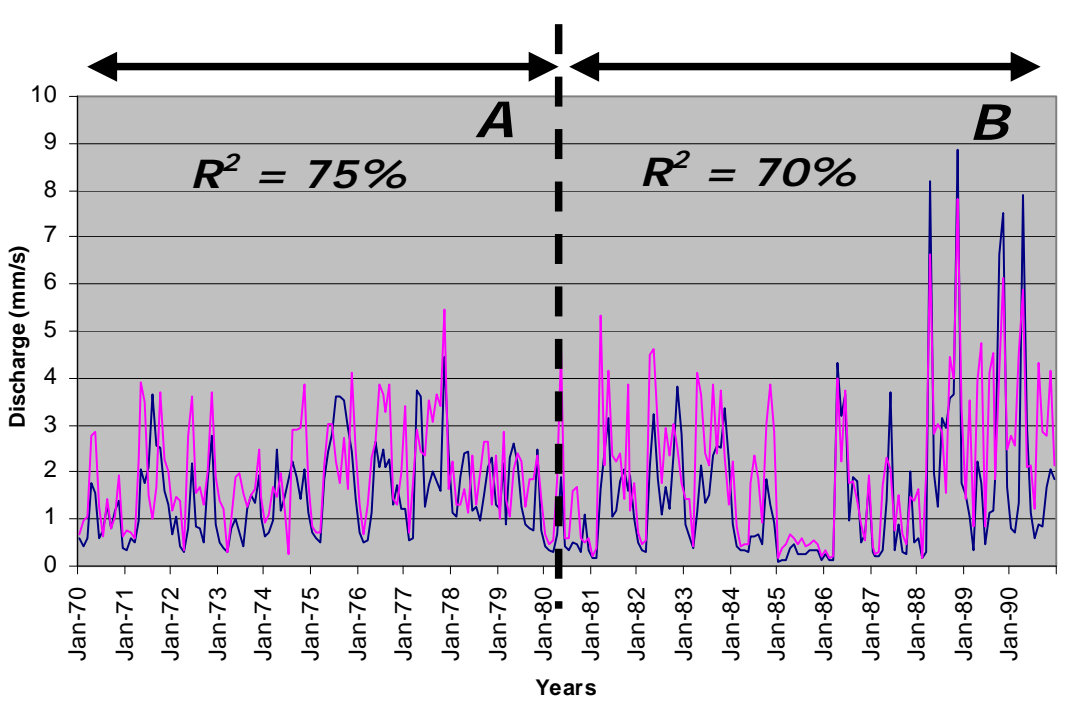

Fig. 2. Calibration (A) and validation (B) phase of the SWAT model.

\section{HESSD}

8, 2477-2501, 2011

\section{Impacts of agricultural}

intensification in Kenya

J. K. Mutiga et al.

\section{Title Page}

Abstract

Introduction

Conclusions

References

Tables

Figures

14

4

Back

Close

Full Screen / Esc

Printer-friendly Version

Interactive Discussion 


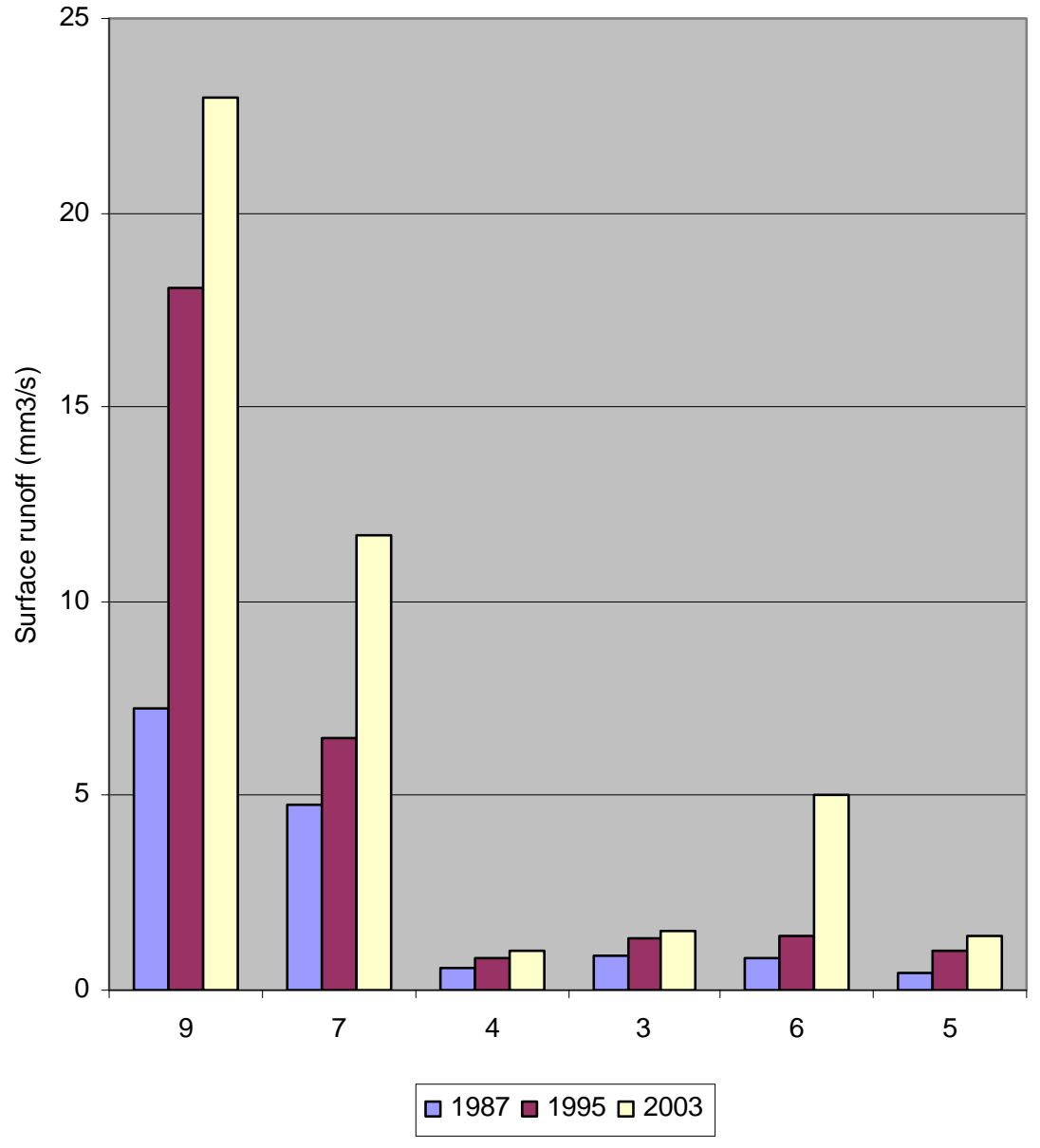

Fig. 3. Generated surface runoff under different land cover/use types at various stations within the basin as shown in Fig 1.

\section{HESSD}

8, 2477-2501, 2011

\section{Impacts of} agricultural

intensification in Kenya

J. K. Mutiga et al.

Title Page

Abstract

Introduction

Conclusions

References

Tables

Figures

14

4

Back

Close

Full Screen / Esc

Printer-friendly Version

Interactive Discussion 


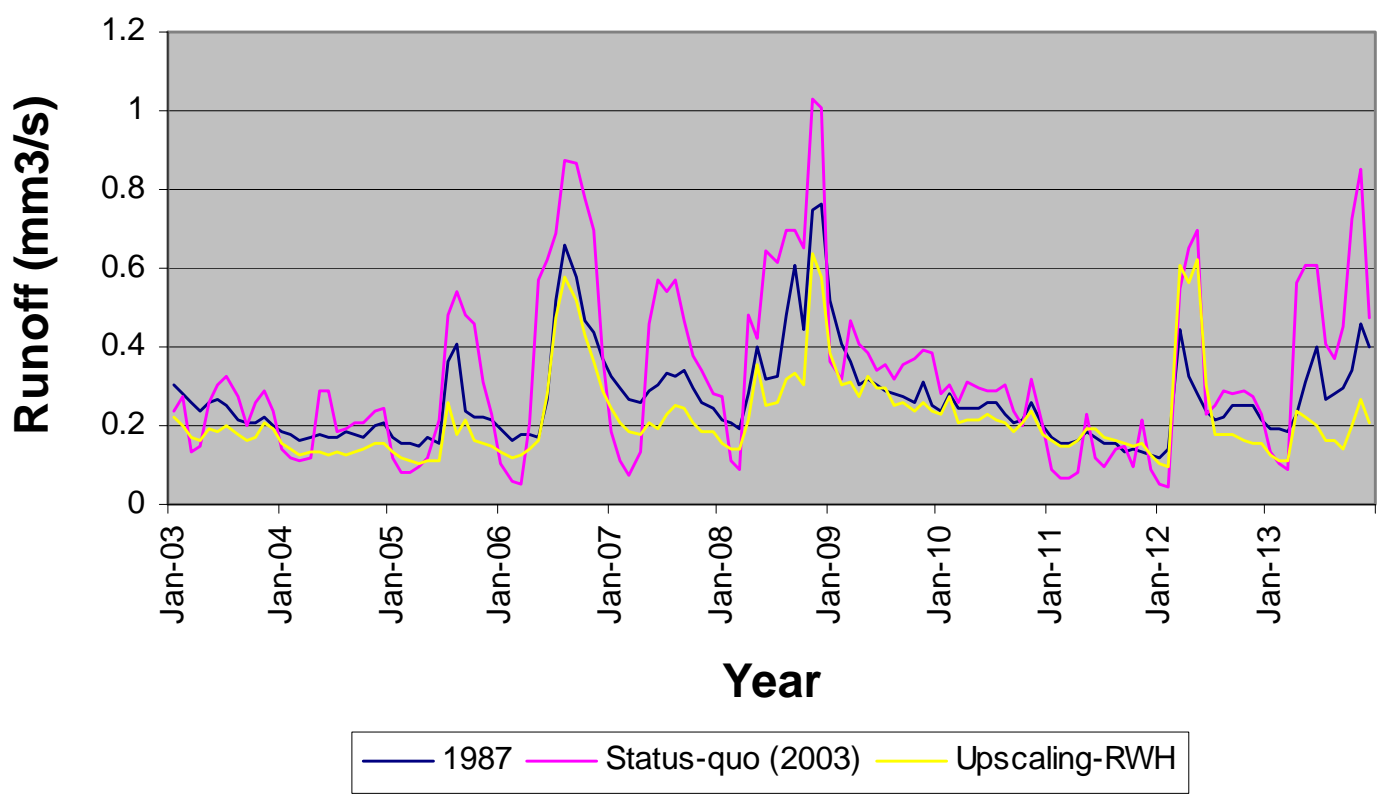

Fig. 4. Simulated surface runoff for three different scenarios at the basin outlet (Archer's Post as shown in Fig. 1).

\section{HESSD}

8, 2477-2501, 2011

\section{Impacts of agricultural} intensification in Kenya

J. K. Mutiga et al.

\section{Title Page}

Abstract

Introduction

Conclusions

References

Tables

Figures

14

4

Back

Close

Full Screen / Esc

Printer-friendly Version

Interactive Discussion 